\title{
Kepemimpinan Kepala Sekolah dan Motivasi Kinerja Guru
}

\author{
Janur Aryanti Maghribi ${ }^{1}, \operatorname{Aspin}^{2}, \&$ Ida Sriwaty Sunarjo ${ }^{3}$ \\ Jurusan Psikologi \\ Fakultas Keguruan dan Ilmu Pendidikan, Universitas Halu Oleo \\ januraryanti099@gmail.com ${ }^{1}$, aspin.psi@gmail.com², ida_sunarjo@ymail.com
}

\begin{abstract}
Abstrak : Guru merupakan figur manusia yang memegang peran 99\% dalam pendidikan. Disaat kebanyakan orang mempermasalahkan tentang pendidikan, sosok guru pasti terlibat dalam pembicaraan tersebut apalagi menyangkut persoalan pendidikan langsung di sekolah. Hal tersebut tidak terlepas dari peran seorang Kepala Sekolah yang menentukan bagi keberhasilan sekolah. Seorang pemimpin seharusnya mempunyai kemampuan yang kuat dalam memimpin suatu sekolah. Sebagai seorang atasan, Kepala Sekolah harus dapat memperhatikan apa yang menjadi kebutuhan orang yang bekerja di bawahnya, sehingga kinerja guru selalu menjadi baik. Penelitian ini mempunyai tujuan untuk mengetahui peran kepemimpinan Kepala Sekolah terhadap motivasi kinerja guru di SMA Negeri 10 Kendari. Jenis penelitian ini ialah kuantitatif dengan desain korelasional. Populasi penelitian berjumlah 38. Sampel penelitian berjumlah 38 pengajar dengan menggunakan teknik total sampling. Instrumen penelitian menggunakan skala kepemimpinan Kepala Sekolah dan skala motivasi kinerja guru. Teknik analisis data adalah analisis regresi sederhana dengan menggunakan SPSS (Statistical Package for the Social Science) versi 23.0. Hasil uji statistik menunjukkan kepemimpinan Kepala Sekolah kategori sedang sebanyak 57,90\% sedangkan kinerja guru kategori sedang sebanyak $60,53 \%$. Analisis regresi sederhana menunjukkan nilai signifikansi 0,000 artinya terdapat peran yang signifikan dari kepemimpinan terhadap motivasi kinerja guru. Penelitian telah menunjukkan peran kepemimpinan kepala sekolah terhadap motivasi kinerja guru memberikan sumbangan sebesar 70,4\% sehingga hipotesis penelitian diterima.
\end{abstract}

Kata Kunci : kepemimpinan kepala sekolah; motivasi kinerja guru

\begin{abstract}
Teachers are human figures who play a $99 \%$ role in education. When most people have an issue with education, the teacher must be involved in the conversation, especially when it comes to direct education in schools. This is inseparable from the role of a school principal that determines the success of the school. A leader should have a strong ability to lead a school. A boss, the principal must be able to pay attention to what the working people need so that the teacher's performance is always good. This study aims to determine the role of the principal's leadership on teacher performance motivation at SMA Negeri 10 Kendari. This type of quantitative research with an correlation design. The study population amounted to 38. The research sample consisted of 38 teachers using a total sampling technique. The research instrument used the Principal leadership scale and the teacher performance motivation scale. The data analysis technique was simple regression analysis using SPSS (Statistical Package for the Social Science) version 23.0. The results of statistical tests showed that the leadership of the principal in the moderate category was $57.90 \%$, while the teacher's performance in the moderate category was 60.53\%. Simple regression analysis shows a significance value of 0.000 , which means that there is a significant role of leadership in teacher performance motivation. Research has shown the role of principal leadership on teacher performance motivation contributes $70.4 \%$ so that the research hypothesis is accepted.
\end{abstract}

Keywords: principal leadership; teacher performance motivation 


\section{Pendahuluan}

Guru adalah seseorang yang menduduki jabatan dan memperoleh peranan penting dalam sekolah. Guru merupakan suatu tenaga profesional yang mempunyai tugas untuk merencanakan dan melakukan proses pembelajaran yang telah menjadi tanggung jawabnya, menilai hasil pembelajaran siswanya, memberikan bimbingan dan pelatihan, serta memberikan pemahaman kepada lingkungan sekitar. Hal tersebut tidak dapat disanggah karena lembaga organisasi sekolah adalah kehidupan pengajar. Sebagian besar pengajar menghabiskan waktunya di sekolah, sisanya yaitu di rumah (Djamarah, 2000).

Guru merupakan sebuah komponen yang menempati kedudukan sangat strategis di dalam organisasi sekolah. Guru merupakan penunjang yang sangat dominan dalam kaitannya dengan meningkatnnya kualitas pendidikan, oleh karena itu pengajar merupakan salah satu bagian yang paling tidak bisa dipisahkan dari pendidikan secara menyeluruh yang terlibat langsung dalam mengajar dan mendidik (Ardiana, 2017). Pengajar merupakan sumber kehidupan yang sangat menentukan bagi keberhasilan pendidikan di sekolah, karena Pengajar merupakan unsur utama yang sangat dekat hubungannya dengan siswa dalam upaya pendidikan sehari-hari di sekolah (Purwanto, Ahiri, \& Momo, 2019).

Guru sendiri mempunyai tugas dan tanggung jawab yang besar terhadap keberhasilan dan kemajuan siswanya, hal ini dapat dipengaruhi oleh motivasi dari guru tersebut dalam meningkatkan kinerjanya. Kata latin dari motivasi adalah "movere" yang artinya "semangat atau daya yang menggerakkan". Motivasi dapat dikatakan sebagai daya penggerak dari dalam diri sseseorang untuk melakukan aktivitas-aktivitas tertentu yang berarti untuk mengapai sesuatu, sesuai yang diharapkan (Sardiman, 2007). Peningkatan kualitas pendidikan merupakan proses peningkatan kualitas yang ada di sekolah itu sendiri dan melalui pengembangan kurikulum dan sistem pemeriksaan, perbaikan sarana dan prasarana di sekolah sangat menunjang bagi kemajuan sekolah (Ekosiswoyo, 2007).

Kinerja adalah keberhasilan dalam bekerja, pelaksana, pencapaian, hasil kerja atau untuk kerja (Mulyasa, 2004). Pencapaian kinerja guru yang optimal didukung oleh dua faktor yaitu faktor eksternal dan faktor internal. Faktor internal yaitu dorongan dalam bekerja, tanggung jawab terhadap tugas. Sedangkan faktor eksternal itu sendiri yaitu penghargaan atas tugasnya, peluang untuk mengembangkan hubungan yang baik sesama guru lainnya, adanya pelatihan, dan kelompok diskusi terarah dan perhatian dari kepala sekolah (Mulyasa, 2007).

Kepala sekolah merupakan suatu kedudukan yang sangat besar peranannya dalam meningkatkan daya pendidikan (Mulyasa, 2004). Pemimpin diangkat untuk menempati kedudukan yang diberikan tanggung jawab untuk mengatur agar terbentuk tujuan bersama dalam mencapai pendidikan. Atasan adalah orang yang berada pada garis terdepan yang membimbing dan mengarahkan segala upaya meningkatkan pembelajaran yang bermutu. Menurut Handayani \& Rasyid (2015) kepala sekolah adalah atasan yang bisa berperanan sangat besar dalam pengembangan pendidikan di sekolah.

Kepala sekolah sebagai atasan dalam suatu sekolah melalui kepemimpinannya mempunyai tugas mengembangkan segala keunggulan yang terdapat di sekolah, sumber kehidupan di sekolah yang dapat dikembangkan yaitu guru dan siswa di sekolah tersebut (Wardani, Munandar, \& Makmuri, 2016).

Kepemimpinan seorang atasan memiliki peranan yang menentukan bagi kemajuan sekolahnya. Atasan yang baik selalu bisa menghadirkan peningkatan kinerja pengajar melalui program pembinaan kemampuannya. Oleh karena 
itu, atasan juga harus mempunyai sifat juga kepribadian yang dapat dicontoh dan mempunyai kemampuan untuk memimpin sebuah organisasi. Kepala sekolah diberikan tanggung jawab untuk memberikan bimbingan, mengarahkan dengan jelas dan motivasi kepada pengajar, sehingga guru melaksanakan tugasnya dengan sempurna yang pada gilirannya dapat meningkatkan kinerja guru itu sendiri (Rosmiati, Ramli, \& Karno, 2020). Kepala sekolah merupakan atasan yang berperan dalam meningkatkan kinerja guru dan mendidik bawahannya dengan baik (Kasidah, Murniati\& Bahrun, 2017).

Kepemimpinan kepala sekolah penting karena melalui kepemimpinan yang baik bisa berperan, membimbing, memantau dan menggerakan orang lain yang mempunyai hubungan dengan perkembangan ilmu dan pelaksanaan pendidikan dan pelajaran agar kegiatan yang ada lebih efisien dan efektif didalam tujuan pendidikan (Astuti, 2018). Kepemimpinan pada dasarnya mempunyai inti penjelasan sebagai sifat, kemampuan, proses atau konsep yang dimiliki oleh diri sedemikian rupa sehingga dapat dilaksanakan, dipatuhi dan dihormati, sehingga orang lain bersedia dengan ikhlas melakukan tindakan dan kegiatan yang diberikan pimimpin tersebut (Rusmawati, 2013).

Sebagai pimimpin, Kepala Sekolah harus memberikan perhatian atas keinginan, kebutuhan utama dan perasaan orang yang melaksanakan tugas di sekolah sehingga kinerja guru dapat berkembang dan selalu terjaga. Di samping itu, kepala sekolah juga diberikan tanggung jawab untuk dapat melakukan tugasnnya sebagai pemimpin dalam mengembangkan tahap pembelajaran dengan menjalankan pengontrolan setiap ruang kelas, pengarahan dan memberikan masukan yang bagus kepada pengajar demi mengembangkan kinerja pengajar. Motivasi adalah rasa yang bersumber dari dalam diri yang bisa membangkitkan dan memberikan kekuatan untuk tetap berada pada tujuan tersebut kepada diri dalam mencapai suatu tujuan tertentu (Setiawan, 2015). Motivasi kerja yaitu agar semua karyawan bisa menimbulkan dorongan dalam diri untuk melakukan suatu kegiatan untuk mencapai tujuan (Subagio, 2015). Dukungan yang luar biasa dari atasan memegang peranan yang sangat penting untuk memberikan dorongan kepada pengajar, sehingga dengan diberikannya semangat yang luar biasa dari kepala sekolah maka kinerja guru diharapkan meningkat menjadi lebih baik juga (Setiyati, 2014).

Pengajar yang mempunyai motivasi tinggi dapat memandang berbagai permasalahan yang terdapat di sekolah sebagai tantangan. Pengajar pasti berusaha sebisa mungkin untuk mengatasi permasalahan yang ada. Adannya perhatian yang memuaskan kepada guru, maka akan dapat menumbuhkan motivasi guru untuk melakukan yang luar biasa dalam melakukan tugas sehingga menimbulkan kerjasama saat melakukan pekerjaan yang berkualitas demi kemajuan sekolahnya (Dewi, 2015).

$\begin{array}{lll}\text { Kinerja guru yang } & \text { besar } \\ \text { mempunyai kemungkinan } & \text { dapat } \\ \text { menghasilkan perubahan yang } & \text { keras } \\ \text { terhadap keberhasilan siswa dalam }\end{array}$
mencapai tingkat kompetensinya. Kinerja guru pasti disangkutkan dengan kepemimpinan kepala sekolah, bahwa kepala sekolah kurang berkomunikasi antar guru, kepala sekolah kurang memberi semangat atau dorongan penuh kepada pengajar sehingga terkadang pengajar malu untuk lebih meningkatkan kemajuannya. Kepemimpinan yang baik pasti bisa mengusahakan pengembangan kinerja para pengajar di sekolah melalui beberapa bimbingan kemampuan tenaga pendidikan. Seorang pemimpin untuk bisa memulai menjalankan tugasnya dengan sangat baik yaitu memiliki sabar, pengertian mencintai terhadap apa yang dipimpinnya agar dapat terjalin 
keharmonisan dalam sekolah (Syamsul, 2017).

Kinerja guru merupakan sebuah pencapaian yang didapat oleh pengajar dalam melakukan tugas yang menjadi tanggung jawabnya didasarkan pada pengalamannya, kesungguhan, niat dan kecakapan dalam berkomunikasi serta penggunaan waktu yang sangat efisien (Sarwan., Taena, \& Karno, 2019). Kinerja guru merupakan keahlian dalam kerja yang diperoleh seorang pengajar, berkaitan dengan tugas yang dilakukannya dan didasarkan pada tanggung jawab profesionalnnya (Rosmiati, Ramli, \& Karno, 2020).

Kinerja guru yang baik dapat terlihat dari pengajar yang aktif di sekolah dan aktif saat memberikan pengajaran, guru mengajar dengan sangat serius menggunakan rancangan pembelajaran, guru mengajar dengan penuh motivasi, memakai metode yang juga beragam setara dengan metode pembelajaran yang siap diajarkan, selain itu juga melakukan evaluasi pengajaran serta menindaklanjuti evaluasi. Dengan demikian, keadaan seperti ini secara otomatis dapat memicu munculnya perubahan peran pengajar dalam proses pengembangan potensi siswanya. Oleh karena itu, hal ini tidak bisa terpisahkan dari peranan atasan dalam menjalankan kepemimpinannya dalam lembaga.

Penunjang dari kinerja guru yang baik yaitu dipengaruhi oleh bagaimana cara seorang pemimpin dalam menjalankan tugas atau perannya di sekolah sehingga dapat menghasilkan kinerja guru yang baik sekolah dan yang bermutu. Para guru mengatakan bahwa mereka akan sangat bersemangat bila saat melakukan tugas atau menyelesaikan tanggung jawab dengan baik, maka kepala sekolah akan memberikan penghargaan seperti pujian. Mereka masih kurang mendapatkan motivasi dari kepala sekolah sehingga berdampak pada guru seperti kurangnya bersemangat dalam menjalankan tugas yang diberikan, dan terkadang lalai dalam menjalankan tugas.

Berdasarkan wawancara yang dilakukan oleh peneliti pada tanggal 23 November 2019 kepada guru SMA Negeri 10 Kendari yang berjumlah 12 orang, dari wawancara tersebut dapat disimpukan bahwa guru berpendapat kepala sekolah sudah menjalankan tugas dengan baik dan memberikan semangat seperti menanyakan pekerjaan apa yang belum terselesaikan akan tetapi mereka merasakan ada hal yang masih diinginkan oleh para guru seperti kepala sekolah tidak hanya memberikan sebuah wacana, akan tetapi memberikan peranan secara langsung di sekolah selain itu juga guru menginginkan rasa ingin bertukar pendapat antara kepala sekolah dan guru sehingga adanya komunikasi timbal balik yang diciptakan agar dapat menjadi seorang pemimpin yang bisa dijadikan teladan bagi guru dan siswa. Selain itu ada beberapa guru juga mengatakan bahwa pendekatan atasan dengan pengajar cenderung pasif, komunikasi yang terjadi cenderung komunikasi satu arah antara kepala sekolah dengan guru, sehingga kurang munculnya harapan yang diinginkan guru untuk bisa menyampaikan harapan mereka.

Beberapa guru memiliki gambaran pemimpin yang masih kurang mewakili, mereka menginginkan seorang pemimpin yang selalu aktif dalam kegiatan apapun yang terdapat di sekolah misalnya kegiatan ekstrakurikuler siswa seperti kegiatan olahraga dan pramuka yang diadakan dalam pertandingan antar sekolah maupun pertandingan lainnya, juga ada harapan bahwa seorang pemimpin yang bisa menjadi teman, seorang pemimpin yang bisa saling berkomunikasi dua arah dan bisa saling memberi saran satu sama lain. Masih kurang adanya penegasan pada guru dan siswa yang terlambat masuk sekolah, hal ini bisa mempengaruhi kegiatan proses belajar mengajar dimana guru mengambil jam mengajar di luar jadwalnya serta beberapa guru juga cenderung monoton 
dalam proses belajar mengajar sehingga membuat siswa-siswinya kurang mengerti terhadap materi yang disampaikan. Selain itu, kurangnya kedisiplinan yang diterapkan kepada guru yang terlambat dan menunda-nunda mengajar di kelas. Peraturan yang telah ditetapkan oleh sekolah seringkali dilanggar oleh guru dan siswa serta terus mengulanginya walaupun telah mendapat teguran. Perlu kita memahami bahwa setiap atasan telah diberikan tanggung jawab untuk bisa mengajarkan dan memberikan apa yang terbaik bagi bawahannya.

Berdasarkan penjelasan di atas, ditemukan bahwa para guru memiliki banyak keinginan dan harapan yang mereka inginkan dari seorang kepala sekolah dan menginginkan motivasi atau dorongan yang lebih dari kepala sekolah mereka sehingga peneliti tertarik seberapa besar peranan yang didapat dari kepala sekolah/pemimpin mereka. Atasan dalam hal ini kepala sekolah harus dapat memberi contoh, pemahaman, penuh pengertian, sabar dan sebisa mungkin saling memberikan motivasi agar semua bisa berjalan sesuai dengan yang di harapkan sehingga dapat menghasilkan kinerja yang memuaskan antara kepala sekolah dan juga guru di sekolah.

Sesuai uraian dan permasalahan di atas, maka peneliti berasumsi bahwa terdapat peran kepemimpinan kepala sekolah terhadap motivasi kerja guru di SMA Negeri 10 Kendari.

\section{Metode Penelitian}

Penelitian ini menggunakan metode kuantitatif dengan desain penelitian expose facto. Terdapat dua variabel dalam penelitian ini yaitu variabel kepemimpinan Kepala Sekolah sebagai variabel bebas dan variabel motivasi kerja sebagai variabel terikat. Populasi penelitian berjumlah 38 guru yang dipilih menggunakan teknik total sampling.

Instrumen pengumpulan data yang digunakan adalah skala kepemimpinan kepala sekolah sebanyak 31 item dan skala motivasi kinerja guru dengan jumlah item sebanyak 26 item. Validitas skala penelitian ini menggunakan koefisien validitas isi Aiken's V yang dirumuskan untuk menghitung content-valid coefficient yang didasari oleh penilaian para ahli. Hasil uji coba skala kepemimpinan kepala sekolah menunjukkan bahwa dari 46 item yang telah dianalisis, 31 item dinyatakan valid sedangkan 15 item lainnya dinyatakan gugur karena tidak memenuhi standar koefisien korelasi yang telah ditetapkan yakni $\geq 0,25$. Sedangkan hasil uji coba skala motivasi kinerja guru menunjukkan bahwa dari 40 item yang telah dianalisis, 26 item dinyatakan valid sedangkan 14 item lainnya dinyatakan gugur. Penelitian ini menggunakan SPSS (Statistical Package for the Social Sciences) versi 23.0 untuk mengetahui nilai reliabilitas dengan melihat skor Cronbach's alpha. Adapun nilai reliabilitas skala kepemimpinan kepala sekolah adalah 0,860 sedangkan nilai reliabilitas skala motivasi kinerja guru adalah 0,804 .

Definisi operasional mengenai variabel penelitian yaitu kepemimpinan kepala sekolah (Mesiono, 2012) adalah sikap kepemimpinan kepala sekolah yang tegas, berwibawa, selalu memberi motivasi, memberikan semangat kepada guru, berkomunikasi yang aktif dengan para guru saling menerima pendapat dan masukan untuk membangun dan mengembangkan kinerja serta memberikan contoh yang baik. Sedangkan motivasi kerja guru (Mulyasa, 2013) yaitu suatu dorongan yang timbul melalui alam bawah sadar guru SMA Negeri 10 Kendari dan suatu kemampuan untuk melaksanakan tugasnya berdasarkan tanggung jawab yang diberikan oleh kepala sekolah seperti datang tepat waktu, mengerjakan nilai tepat waktu, mengenal dan memahami siswanya, membimbing siswa dengan baik, dan ikut serta dalam kegiatan sekolah. Penelitian ini menggunakan analisis deskriptif untuk memberikan deskripsi mengenai data dari variabel yang 
diukur. Untuk mengetahui apakah data terdistribusi secara normal yakni menggunakan teknik Kolmogorov Smirnov, uji linearitas menggunakan test from linearity, serta pengujian hipotesis menggunakan teknik analisis regresi sederhana dengan menggunakan SPSS (Statistical Package for the Social Sciences) versi 23.0.

\section{Hasil Penelitian dan Pembahasan}

Pada tabel di bawah ini, dapat diketahui bahwa sampel penelitian berjumlah 38 guru di SMA Negeri 10 Kendari. Pada variabel kepemimpinan diketahui nilai minimun yang diperoleh sama dengan 80, nilai maksimum sama dengan 137 dengan mean yang diperoleh 108, 1579 sehingga diperoleh nilai standar sebesar 17,19448. Sedangkan pada variabel motivasi kinerja guru diketahui nilai minimun yang diperoleh sama dengan 64, nilai maksimum sama dengan 117 dengan mean yang diperoleh sama dengan 87, 8947 sehingga diperoleh nilai standar deviasi sebesar 15,43564.

Tabel 1. Data deskriptif penelitian

\begin{tabular}{lccccc}
\hline & $N$ & Xmin & Xmax & Mean & $\begin{array}{l}\text { Standar } \\
\text { deviasi }\end{array}$ \\
\hline $\begin{array}{l}\text { Kepemim } \\
\text { pinan KS }\end{array}$ & 38 & 80 & 137 & $\begin{array}{l}108,15 \\
79\end{array}$ & 17,19448 \\
$\begin{array}{l}\text { Kinerja } \\
\text { Guru }\end{array}$ & 38 & 64 & 117 & $\begin{array}{l}87,894 \\
7\end{array}$ & 15,43564 \\
\hline
\end{tabular}

Deskriptif data penelitian di atas dapat dijadikan dasar dalam pengkategorian sampel penelitian. Tujuan dari kategorisasi ini untuk menempatkan subjek ke dalam suatu kelompok yang bertahap menurut rangkaian berdasarkan perlengkapan yang diukur (Azwar, 2017).

Berdasarkan data tabel di bawah ini, ditemukan bahwa dari 38 subjek, terdapat 4 subjek yang mengalami tingkat kategori kepemimpinan kepala sekolah yang rendah dengan persentase 10,53\%, subjek dalam kategori sedang sebanyak 22 subjek dengan persentase $57,90 \%$, dan 12 subjek dalam kategori tinggi dengan persentase $31,57 \%$.
Tabel 2. Kategorisasi kepemimpinan kepala sekolah

\begin{tabular}{lccc}
\hline Kategori & \multicolumn{1}{c}{ skor } & $N$ & Presentase \\
& & & \\
\hline Rendah & $\mathrm{X}<(90,96342)$ & 4 & $10,53 \%$ \\
Sedang & $(90,96342) \leq \mathrm{X}$ & 22 & $57,90 \%$ \\
& $<(125,35238)$ & & \\
Tinggi & $(125,35238) \leq \mathrm{X}$ & 12 & $31,57 \%$ \\
Jumlah & & 38 & $100 \%$ \\
\hline
\end{tabular}

Berdasarkan data tabel di bawah ini, ditemukan bahwa dari 38 subjek terdapat 5 subjek yang memiliki tingkat kategori motivasi kinerja guru yang rendah dengan persentase $13,16 \%$, subjek dalam kategori sedang sebanyak 23 subjek dengan persentase $60,53 \%$, dan 10 subjek dalam kategori tinggi dengan persentase $26,31 \%$.

Tabel 3. Kategorisasi motivasi kinerja guru

\begin{tabular}{|c|c|c|c|}
\hline Kategori & skor & $N$ & Presentase \\
\hline Rendah & $\mathrm{X}<(72,45906)$ & 5 & $13,16 \%$ \\
\hline Sedang & $\begin{array}{l}(72,45906) \leq \quad X \\
<(103,33034)\end{array}$ & 23 & $60,53 \%$ \\
\hline $\begin{array}{l}\text { Tinggi } \\
\text { Jumlah }\end{array}$ & $(103,33034) \leq X$ & $\begin{array}{l}10 \\
38\end{array}$ & $\begin{array}{l}26,31 \% \\
100 \%\end{array}$ \\
\hline
\end{tabular}

Tabel di bawah ini menjelaskan peran kepemimpinan kepala sekolah dengan motivasi kinerja guru. Hasilnya menunjukkan bahwa tidak terdapat peran kepemimpinan kepala sekolah yang rendah dan motivasi kinerja guru yang tinggi. Dari data tersebut tidak terdapat peran kepemimpinan kepala sekolah yang tinggi dan motivasi kinerja guru dalam kategori rendah.

Data lain ditemukan terdapat 9 guru yang merasakan peran kepemimpinan kepala sekolah tinggi dan motivasi kinerja guru yang tinggi pula. Sebanyak 10 guru merasakan peran kepemimpinan kepala sekolah yang sedang juga berpengaruh kepada motivasi kinerja guru yang sedang dan pada kategori guru yang merasakan peran kepemimpinan kepala sekolah dalam kategori rendah dan motivasi kinerja guru 
rendah, terdapat 1 guru yang mengalami kondisi tersebut.

Tabel 4. Kategorisasi tingkat kepemimpinan kepala sekolah dan motivasi kinerja guru

\begin{tabular}{ccccc}
\hline Motivasi & \multicolumn{3}{c}{ Kepemimpinan KS } & \multirow{2}{*}{ Total } \\
KG & Tinggi & Sedang & Rendah & \\
\hline Tinggi & 9 & 9 & 0 & 18 \\
Sedang & 3 & 10 & 3 & 16 \\
Rendah & 0 & 3 & 1 & 4 \\
Total & 12 & 22 & 4 & 38 \\
\hline
\end{tabular}

Uji normalitas data pada tabel di bawah ini menggunakan teknik OneSample Kolmogorov-Smirnov dengan SPSS 23.0 for windows. Hasilnya menunjukkan nilai signifikansi pada variabel kepemimpinan kepala sekolah sebesar 0,200 sedangkan pada variabel motivasi kinerja guru nilai signifikansi yang diperoleh adalah 0,200. Nilai tersebut diketahui lebih besar dari 0,05 (P $\geq 0,05$ ). Hal ini menunjukkan bahwa data dari kedua variabel berdistribusi secara normal.

Tabel 5. Uji normalitas

\begin{tabular}{lcc}
\hline \multicolumn{3}{c}{ One-Sample Kolmogorov-Smirnov Test } \\
& Signifikansi & Keterangan \\
\hline Kepemimpinan KS & 0,200 & $\mathrm{P} \geq 0,05$ (Normal) \\
Motivasi KG & 0,200 & $\mathrm{P} \geq 0,05$ (Normal)
\end{tabular}

Uji linearitas data pada tabel di bawah ini menggunakan test for linearity pada program SPSS 23.0 for windows menunjukkan nilai signifikansi deviation from linearity sebesar 0,620. Nilai ini lebih besar dari $0,05 \quad(\mathrm{P} \geq 0,05)$, menunjukkan bahwa data variabel kepemimpinan kepala sekolah dan motivasi kinerja guru memiliki hubungan yang linear.

Tabel 6. Uji linearitas

\begin{tabular}{lll}
\hline \multicolumn{1}{c}{ Variabel } & $\begin{array}{l}\text { Sig. deviation } \\
\text { from linearity }\end{array}$ & Keterangan \\
\hline Kepemimpinan KS & 0,620 & Alat ukur (Linear) \\
Motivasi KG & 0,620 & Alat ukur (Linear) \\
\hline
\end{tabular}

Uji hipotesis dalam penelitian ini dilakukan dengan menggunakan analisis regresi sederhana menunjukkan nilai signifikansi 0,000 . Nilai ini lebih kecil dari 0,01 , sehingga dapat dikatakan terdapat peran kepemimpinan kepala sekolah yang signifikan terhadap motivasi kinerja guru.

Tabel 7. Uji analisis regresi sederhana

\begin{tabular}{llll}
\hline \multicolumn{1}{c}{ Model } & \multicolumn{3}{c}{ Unstandardized Coefficients } \\
& \multicolumn{1}{c}{$B$} & Std. Error & \multicolumn{1}{c}{ Sig } \\
\hline 1 (Constant) & 6.457 & 8.919 & .474 \\
KKS & .753 & .081 & .000 \\
\hline
\end{tabular}

Hasil analisis regresi sederhana yang dilakukan dengan perhitungan SPSS 23.0 menunjukkan nilai RSquare sebesar 0,704 yang mengandung arti bahwa kepemimpinan kepala sekolah memberikan sumbangan efektif terhadap motivasi kinerja guru sebesar 70,4\%.

Tabel 8. Koefisien determinasi ( $R$ Square)

\begin{tabular}{lclc}
\hline Model & $R$ & $R$ Square & Adjusted R Square \\
\hline 1 & 0,839 & 0,704 & 0,695 \\
\hline
\end{tabular}

Penelitian ini memiliki tujuan untuk menjawab hipotesis apakah terdapat peran dalam kepemimpinan Kepala Sekolah terhadap motivasi kinerja guru di SMA Negeri 10 Kendari. Berdasarkan hasil uji hipotesis dari kedua variabel tersebut, ditemukan kepemimpinan Kepala Sekolah mempunyai peranan yang besar terhadap motivasi kinerja guru di SMA Negeri 10 Kendari sehingga hipotesis dalam penelitian ini diterima.

Pada umumnya atasan dalam memimpin memiliki peran yang menentukan bagi keunggulan sekolah. Atasan berusaha memiliki sikap atau sifat dan kemampuan untuk menjadi atasan sebuah sekolah yang bertanggung jawab. Aktivitas memimpin pada dasarnya 
meliputi suatu hubungan dan adanya satu orang yang memberikan pengaruh kepada orang lain agar mereka ingin bekerja ke tujuan pencapaian bersama (Mesiono, 2012). Seorang kepala sekolah yang melakukan tugas dengan sungguhsungguh dan menjalankan dengan ikhlas merupakan perbuatan yang positif yang dapat dicontoh bagi para pengajar ada di sekolah. Saat kepala sekolah dan para guru melakukan bersama-sama maka akan terjalin kerja sama yang baik antar keduanya.

Mulyasa (2013) menyatakan bahwa kinerja yaitu hasil komunikasi antara dukungan dengan potensi, orang yang tinggi potensinya tetapi rendah motivasinya, akan menghasilkan kinerja yang rendah, demikian halnya orang yang bermotivasi tinggi tetapi potensinya rendah. Kinerja mempunyai hubungan dekat dengan perbandingan. Oleh sebab itu perlu diukur standar kinerja sebagai panutan dalam memberikan perbedaan antara yang dilakukan dengan yang diinginkan dengan pekerjaan atau kedudukan yang telah dipercayakan kepada seseorang. Oleh karena itu seorang pemimpin sangat dibutuhkan perannya dalam kemajuan kinerja pengajar di sekolah.

Penelitian ini bertujuan untuk mengetahui apakah terdapat peran kepemimpinan kepala sekolah terhadap motivasi kinerja guru. Hasil penelitian ini menunjukkan bahwa terdapat peran kepemimpinan kepala sekolah terhadap motivasi kinerja guru, dalam hal ini hipotesis yang diajukan dalam penelitian ini diterima.

Penelitian ini searah dengan penelitian yang telah dilakukan oleh Nurani, \& Sarino (2017) mengenai peran kepemimpinan seorang mengembangkan motivasi kerja dalam meningkatkan kinerja pengajar SMK. Hasil dari penelitian tersebut diketahui bahwa kepemimpinan kepala sekolah dan motivasi kerja terdapat pengaruh yang positif terhadap kinerja guru, baik sebagian maupun menyeluruh.
Berdasarkan wawancara yang dilakukan oleh peneliti pada tanggal 23 November 2019 kepada 12 guru SMA Negeri 10 Kendari, beberapa guru mengatakan mereka inginkan seorang pemimpin yang selalu aktif dalam kegiatan apapun yang ada di sekolah misalnya kegiatan ekstra kurikuler siswa seperti kegiatan olahraga dan pramuka yang diadakan dalam pertandingan antar sekolah maupun pertandingan lainnya, juga ada harapan bahwa seorang pemimpin yang bisa menjadi teman, seorang pemimpin yang bisa saling berkomunikasi dua arah dan bisa saling memberi saran satu sama lain, seorang pemimpin yang tidak hanya memberikan sebuah wacana akan tetapi memberikan peranan secara langsung.

Selain itu, beberapa guru lainnya juga mengatakan bahwa kepala sekolah cenderung pasif, dan jarang berdiskusi. Dari situasi tersebut sehingga guru merasa kurang bersemangat dalam melakukan arahan dari kepala sekolah dan yang ada hanya rasa pekerjaan yang dilakukan sekarang ini hanya sebuah rasa tanggung jawab sebagai guru dan menjadi monoton atau tidak kreatif sehingga dapat mempengaruhi kinerja guru biasa menurun. Guru di SMA 10 mereka akan sangat bersemangat bila melakukan tugas atau menyelesaikan tanggung jawab dengan baik, maka kepala sekolah akan memberikan penghargaan seperti pujian atau reward dan itu adalah suatu bentuk motivasi dari kepala sekolah yang mereka inginkan. Dari penelitian tersebut bahwa peran kepala sekolah sangat signifikan dengan kinerja guru, oleh sebab itu peran kepemimpinan sangat mempengaruhi hasil dari kinerja guru di sekolah.

Hal ini didukung oleh pendapat Sardiman (2007) bahwa guru mendapatkan tanggung jawab dan tugas yang besar terhadap kemajuan dan keberhasilan siswanya. Hal ini mempengaruhi motivasi dari guru tersebut dalam meningkatkan kinerjanya di sekolah. 


\section{Kesimpulan}

Berdasarkan hasil penelitian, maka dapat disimpulkan bahwa hipotesis dalam penelitian ini diterima.Uji hipotesis yang dilakukan dengan menggunakan analisis regresi sederhana menunjukkan nilai yang signifikan. Hasil analisis regresi sederhana pada model $R$ Square menunjukkan bahwa kepemimpinan kepala sekolah memberikan sumbangan efektif terhadap motivasi kinerja guru. Hal ini dapat dilihat dari hasil analisis regresi tabel koefisien yang menunjukkan nilai konstanta dan nilai koefisien regresi yang besar.

Sebaiknnya Kepala Sekolah dapat memberikan ruang untuk guru seperti saling terbuka satu sama lain dan memberikan kesempatan untuk guru mengeluarkan ide-idennya. Bagi guru diharapkan agar lebih terbuka dalam persoalan apapun yang mereka rasakan dalam lingkungan sekolah yang berhubungan dengan kepala sekolah dan sesama rekan kerja.

\section{Daftar Pustaka}

Ardiana. E. T. (2017). Pengaruh motivasi kerja guru terhadap kinerja guru akuntansi SMK di kota Madiun. Jurnal Akuntansi dan Pajak, 17 (2).

Astuti, S, W. (2018). Hubungan kepemimpinan kepala sekolah dengan kinerja guru di SMK Swasta Bisnis Manajemen kecamatan Padang Barat kota Padang. Jurnal Bahana Manajemen Pendidikan, 7(2), 1623.

Azwar. (2017). Metode penelitian psikologi. Yogyakarta: Pustaka Pelajar.

Dewi. A. T. (2015). Pengaruh profesionalisme guru dan motivasi kerja terhadap kinerja guru ekonomi di SMA se-kota Malang. Jurnal Pendidikan Ekonomi, 3(1).

Djamarah, S.B. (2000). Guru dan anak didik dalam interaksi edukatif. Jakarta: Rineka Cipta.

Ekosiswoyo. R. (2007). Kepemimpinan kepala sekolah yang efektif kunci pencapaian kualitas pendidikan. Jurnal Ilmu Pendidikan, 14(2), 7682.

Handayani, T. \& Rasyid A. A (2015). Pengaruh kepemimpinan kepala sekolah, motivasi guru, dan budaya organisasi terhadap kinerja guru SMA Negeri Wonosobo. Jurnal Akuntabilitas

Manajemen Pendidikan, 3(2).

Kasidah., \& Murniati A. R., \& Bahrun. (2017). Kepemimpinan kepala sekolah dalam meningkatkan kinerja guru Sekolah Dasar Luar Biasa pada Negeri Banda Aceh. Jurnal Magister Administrasi Pendidikan Universitas Syiah Kuala, 5(2), 127-133.

Mesiono. (2012). Manajemen organisasi. Bandung: Citapustaka Media Perintis.

Mulyasa, E. (2004). Kurikulum berbasis kompetensi. Bandung: Remaja Rosda Karya Offset.

Mulyasa, E. (2007). Menjadi kepala sekolah profesional. Bandung: PT. Remaja Rosdakarya.

Mulyasa, E. (2013). Pengembangan dan implementasi kurikulum 2013. Bandung: PT Remaja Rosdakarya.

Nurani, R. T., \& Sarino, A (2017). Peran kepemimpinan kepala sekolah dan motivasi kerja dalam meningkatkan kinerja guru Sekolah Menengah Kejuruan. Jurnal Pendidikan 
Manajemen perkantoran, 2(1), 6677.

Purwanto, P., Ahiri, J., \& Momo, A. H. (2019). Pengaruh iklim kerja dan motivasi kerja terhadap kinerja guru SMKN di kota Kendari. Jurnal Wahana Kajian Pendidikan IPS, 3(2), 20-34.

Rosmiati. R, Ramli. R, \& Karno. E, (2020). Hubungan motivasi kerja dan gaya kepemimpinan kepala sekolah dengan kinerja guru SMK Negeri di kota Kendari. Jurnal Wahana Kajian Pendidikan IPS. 4(2), 92-104.

Rusmawati, V. (2013). Peran kepemimpinan kepala sekolah dalam upaya meningkatkan disiplin kerja guru pada SDN 018 Balikpapan. Jurnal Administrasi Negara 1(2), 395-409.

Sardiman, A. M. (2007). Interaksi dan motivasi belajar mengajar. Jakarta: PT. Raja Grafindo Persada.

Sarwan, S., Taena, L., \& Karno, E. (2019). Hubungan kompetensi guru dan iklim kerja dengan kinerja guru SD Negeri. Jurnal Wahana Kajian Pendidikan IPS, 3(2), 1-8.

Syamsul, H. (2017). Penerapan kepemimpinan kepala sekolah dalam meningkatkan kinerja guru pada jenjang Sekolah Menengah Pertama (SMP). Jurnal Idaarah 1(2).

Setiawan, C. K (2015). Pengaruh motivasi kerja terhadap kinerja karyawan level pelaksanaan di divisi operasi PT. Pusri Palembang. Jurnal Psikologi Islam, 1(2) 43-53.
Setiyati, S. (2014). Pengaruh kepemimpinan kepala sekolah, motivasi kerja, dan budaya sekolah terhadap kinerja guru. Jurnal Pendidikan Teknologi dan Kejuruan, 22(2).

Subagio. M. (2015). Pengaruh kecerdasan emosional, motivasi kerja, dan sikap kerja terhadap kinerja karyawan pada PT Ithaca Resources. Jurnal Manajemen, XIX (01), 101-120.

Wardani, A., Munandar, M. A., \& Makmuri. (2016). Peran kepemimpinan kepala sekolah perempuan terhadap motivasi kerja guru (Studi Di SMAN 12 Semarang). Unnes Civic Education Journal, 2(2), 8-15. 